\title{
International strategic alliances of small biotechnology firms: a second-best option?
}

\author{
Sophie Veilleux \\ Department of Management, \\ Faculty of Business Administration, \\ Université Laval, \\ Pavillon Palasis-Prince, Office 1429, \\ 2325, rue de la Terrasse, \\ Quebec, G1V 0A6, Canada \\ Fax: 418-656-2624 \\ E-mail: Sophie.Veilleux@fsa.ulaval.ca
}

\begin{abstract}
International strategic alliances have often been presented as the main growth factor for dedicated biotechnology firms (DBFs). Alliances bring resources such as complementary knowledge and financial resources to DBFs. They help these smaller firms conduct R\&D, and costly and long clinical essays and regulations. They build bridges with foreign capital and product markets. Even if some authors have noticed that alliances are not always beneficial or feasible, the main picture has not been altered: they are still presented as a bounty for smaller R\&D biotechnology firms. Our research, based on in-depth interviews of samples of DBFs in Montreal and Boston, suggests that, in both clusters, they use alliances as a second-best option. The preferred strategy is to conduct in-house R\&D supported by venture capital and capital market funds, and only sign alliances at the latest possible time, in order to complete the $\mathrm{R} \& \mathrm{D}$ process.
\end{abstract}

Keywords: dedicated biotechnology firms; DBFs; strategic alliances; internationalisation; growth factors; small and medium size firms; venture capital; timing; country-specific characteristics; strategic alliance goals; strategic alliance governance structure; partner size.

Reference to this paper should be made as follows: Veilleux, S. (2014) 'International strategic alliances of small biotechnology firms: a second-best option?', Int. J. Biotechnology, Vol. 13, Nos. 1/2/3, pp.53-65.

Biographical notes: Sophie Veilleux is a Professor of Technology Entrepreneurship at Université Laval. Her research interests include structural and behavioural issues of international strategic alliances with a special focus on high technology industries. She holds a $\mathrm{PhD}$ in Management of High Technology Firms (specialisation in international entrepreneurship) and an MBA in International Business. Her most significant works on internationalisation of biotechnology firms through alliances have been published in Journal of Business Strategy and International Journal of Business and Globalisation. 


\section{Introduction}

Dedicated biotechnology firms (DBFs) ${ }^{1}$ almost invariably situate themselves in regional clusters where they are neighbours to large research universities and public laboratories. Such institutions bring them the necessary ideas, personnel and incubation facilities to begin conducting R\&D. The co-location of DBFs and research institutions is a universal phenomenon (Lemarié et al., 2001; McKelvey et al., 2003; Niosi, 2005; Powell et al., 2002). Many authors have mentioned that DBFs benefit from international strategic alliances, defined as a contractual agreement between at least two partners toward the achievement of a mutually beneficial goal, in a determined amount of time (Deeds and Hill, 1996; Coombs and Deed, 2000). These goals may either be about one or more of the following functions: research and development, production or marketing. The agreement may also take different governance structures such as in-licensing, cooperation in R\&D, out-licensing, joint ventures or mergers and acquisitions ( $\mathrm{Li}$ et al., 2010). They may be with universities or research institutes, other biotechnology or pharmaceutical firms (Baum et al., 2000). Depending upon the required resources and capabilities, the size of the corporate partner may vary (Tyebjee and Hardin, 2004). Strategic alliances increase small firm capabilities; they also provide new assets to DBFs, particularly complementary knowledge and financial resources (Das and Teng, 2000; Gomes-Casseres et al., 2006). Strategic alliances allow smaller firms to access foreign capital and product markets, comply with different national drug regulations and conduct costly and complex clinical essays. In addition, the literature has observed that local networks of biotechnology firms tend to be more significant than international ones, and the opposite tends to be true when firms mature, and their project portfolio becomes more attractive and valuable (Lemarié et al., 2001; Fontes, 2005). R\&D partnerships are the first step towards internationalisation for DBFs (Veilleux et al., 2011).

However, some scholars, if not a majority of them, have underscored the fact that not all strategic alliances are always successful, and some of them are neither beneficial nor detrimental (Kogut, 1989). Thus, the search for factors explaining differential performance was launched (Gulati, 1995, 1998). Madhok and Osegowitsch (2000) found that the country of origin is a key contextual factor shaping a firm's cooperation capabilities and competitiveness. It also shapes the industry through the availability of academic knowledge, public research funds and venture capital. Other authors have also found significant differences in the kind of international strategic alliances that DBFs tend to conclude based on the allies' country of origin (Fontes, 2005).

Lerner and Merges (2000) argued that early stage DBFs' strategic alliances may turn to the benefit of the stronger partner, particularly during periods of little financial activity. For example, in the human health sector, strategic alliances with large pharmaceutical corporations are becoming the main source of financing for DBFs: "These periods are frequently termed 'buyer's markets'. The theoretical literature suggests that financing constraints may drive R\&D firms to cede control rights in a buyer's market" [Lerner and Merges, (2000), p.127].

Others found that strategic alliances were not the only, or even the most important factor for DBF growth (Niosi, 2003). Similarly, Zollo et al. (2002) observed that strategic alliances performance in biotechnology depended on the partners' experience and, more specifically, on the smaller partners' experience. These authors conclude that strategic alliances are not always the panacea that the literature has often depicted. 
In addition, venture-capital often appears as a key condition of growth. Baum and Silverman (2004) found that venture capital does more than 'pick winners'. It also builds up new firms by bringing them both capital and credibility. It is the second step, after patents, in the dynamic circle of growth in human health DBF (Niosi, 2003). In an environment characterised by scant venture-capital, what is the impact of strategic alliances on a DBF's growth? What is the best sequence of financial resource acquisition for a small biotechnology firm?

\section{US biotechnology environment}

The USA is the world leader in biotechnology, both in sciences and in commercial applications, with its $1,750 \mathrm{DBFs}$, as well as the most firms with large sales and profits. In 2008, 371 US biotechnology firms were publicly quoted, more than any other country. Moreover, the USA has the largest venture-capital pool in biotechnology, representing close to $\$ 4$ billion and still growing. Furthermore, US venture capitalists have 50-years of experience in supporting promising technology-based firms. The USA hosts the National Institutes of Health, an institution spending over 30 billion dollars a year in health $\mathrm{R} \& \mathrm{D}$, both in-house and through grants for private and academic research. Additionally, the USA has large granting agencies, such as the National Science Foundation, which are unparalleled in the world in terms of quality and volume of university research support. The Small Business Innovation Research Program (SBIRP), launched in 1982, funds private companies exploring and developing public research results. SBIRP spent over 2 billion dollars supporting R\&D in smaller firms, including dozens of DBFs. In addition, a majority of US states have implemented similar regional programs to support such technology-based firms.

\section{Canadian biotechnology environment}

Canadian Government support for biotechnology research has been significant considering the size of its economy. In 2008, the federal government spent some US $\$ 920$ million. However, most of this amount was attributed to government laboratories or to academic research, not necessarily for business R\&D. According to the OECD, Canada ranks third in total biotechnology R\&D expenditures in the business sector, behind the USA and France (van Beuzekom and Arundel, 2009). In 2008, Canadian venture-capital from all sources (corporate, institutional and public) for all sectors was only $\$ 1.2$ billion, about $20 \%$ of which was invested in biopharmaceutical firms. Not only is the Canadian venture-capital pool smaller than the US one; the average size of Canadian investments is some \$3.7 million, compared to $\$ 7.6$ million in the USA, leaving Canada in second place worldwide. Moreover, Canadian venture-capital funds go to a small set of companies from which new start-ups and early-stage corporations are excluded. Since 1980, despite their limited resources, Canadian firms have been fast followers, with the development of close to 1,000 DBFs, some 380 of which are still in operation. Evidence of the dynamism of the Canadian sector is also provided by the number of publicly traded biotechnology firms and their average sales. By the end of 2008, 72 Canadian DBFs were quoted on stock exchanges (Ernst \& Young, 2009). Although Canadian biotechnology companies are operating 
within a much smaller capital pool than US firms (Thomson Reuters, 2009), they succeed in ranking second in average sales per DBF, behind the USA.

In spite of the different funding opportunities, Canadian and US firms basically operate under similar patterns. The majority of them are university spin-offs, receive US and Canadian patents, obtain venture capital, develop products and sign strategic alliances with chemical or pharmaceutical corporations (Niosi and Bas, 2001; Niosi and Banik, 2005; Powell et al., 2002; Rothaermel and Deeds, 2006). However, US biotechnology firms are larger and more successful than Canadian ones. How could this gap be explained? Was it due to particular types of relationships with academic institutions, to diverse financial strategies, or to different market sizes?

\section{Research propositions}

The literature shows that even if the number of new technology firm strategic alliances keeps growing, success is far from guaranteed. Numerous factors, including country academic capabilities, geographical distance, and the availability of venture-capital amongst others, have an impact on partnerships (Fontes, 2005; Madhok and Osegowitsch, 2000; Baum and Silverman, 2004). Furthermore, strategic alliances are not the first financial source that DBFs access. We suggest here that because of such uncertain results, and even if DBFs know that strategic alliances lie somewhere in their future and are conditions of their final success, DBFs prefer to advance their projects as far as possible using alternative sources of knowledge and funds other than large-scale partnerships with pharmaceutical firms. Such alternative sources are academic and governmental organisations in the area of complementary knowledge, angel and venture-capital, all as sources of financial resources.

In countries with smaller domestic markets, a smaller university system, and particularly those without a strong domestic pharmaceutical industry, DBFs are forced to go abroad to conduct $\mathrm{R} \& \mathrm{D}$, production or marketing strategic alliances with large pharmaceutical firms (McKelvey et al., 2003; Gilding, 2008; Veilleux et al., 2012). US firms find complementary resources at home, while Canadian DBFs are forced to search for them in the international arena.

After the literature review, and based on previous findings, we draw the following propositions for our exploratory study in order to answer our main research question: Are international strategic alliances the best option for human health biotechnology firms?

Proposition 1 DBFs evolving in a scarce venture-capital home environment conduct international strategic alliances to overcome their lack of financial resources. The level of internationalisation of biotechnology firms, as defined by the number of international strategic alliances, depends on country-specific characteristics: the smaller the home country of DBFs, the larger the number of international strategic alliances they breed.

Proposition 2 The timing of the first international strategic alliance is related to the availability of the home market venture-capital: the lower the amounts of venture-capital, the faster the entry into international strategic alliances. 


\section{Methodology}

Thus, in spite of the observed similarities, using an exploratory study with descriptive results, we wanted to shed more light on the patterns of funding and knowledge acquisition by Canadian DBFs in the human health sector compared with their most successful US counterparts. The present study was conducted in Boston and Montreal, two of the largest North American biotechnology clusters, with two random samples of US and Canadian-owned and -controlled dedicated human health biotechnology firms. Companies were interviewed personally by the researcher with a questionnaire. Interviews took between one and two hours. Questions were asked on the area of activity, the development stage achieved by their most advanced product, year of foundation, patents, products in the pipeline and on the market, number of employees, information on venture capital obtained (amounts, sources, type and goal, as well as the year of investments), stock exchange experience if any, amount of initial public offering (IPO), internationalisation process, strategic alliances and cooperation, including local, national and international, with academic, financial and corporate organisations including: dates, countries, budgets, number of strategic alliances, governance structure, goals of partnerships and advantages resulting from the strategic alliances. Corporate partner size was categorised in small and medium size companies compared to larger firms, based on the number of employees at a turning point of 250 employees (OECD, 2006).

\section{Descriptive results}

Table 1 presents the profile of sample firms: 12 Boston firms and 14 Montreal firms are involved in therapeutics whereas two of the 16 Montreal firms are in diagnostics. The firms have mainly reached development stages (preclinical and clinical phases), rather than being in research. Boston firms are older (11 years) than the Montreal ones (eight years). They are more advanced, evidenced by having more products on the market and in Phase III clinical trials. Both diagnostic firms from Montreal were already selling their products. Bostonian firms have more patents, but a similar number of products. Bostonian firms are larger with a median number of employees of 115, whereas the Montreal ones have a median of 25 . On the financial side, there is also a substantial difference in terms of percentages of firms that have obtained venture-capital: $92 \%$ for Boston firms compared to $69 \%$ for those in Montreal. Moreover, Bostonian firms received almost three times the median amount of venture-capital, and the amount of the IPO of those on the stock market was more than seven times higher.

In Table 2, the distribution of the 430 total strategic alliances was shown for both sets of firms, at the local and international levels. Table 3 describes all 430 strategic alliances in terms of goals, R\&D partners' organisation type, governance structure, and corporate partner size. They were then split into Table 4 and Table 5, based on their locations. While Table 4 characterises the 180 local strategic alliances, Table 5 presents the 250 international strategic alliances. As show in Table 5, the Montreal firms developed, on average, more R\&D strategic alliances, 8.4 per firm against 6.5 for Boston companies. Both at the local and international level, while R\&D partners of Boston firms are corporate organisations, the Montreal firms collaborate more with universities. They also had more production and more marketing agreements. Boston's firms had more multi-functional agreements than Montreal's firms. Note that Montreal's firms have 
conducted more in-licensing agreements and R\&D collaborations. Boston outperforms in out-licensing, mergers and multi-governance structure agreements.

Table 1 Profile of sample firms in human health biotechnology

\begin{tabular}{lcc}
\hline Sample profile & Boston $(n=12)$ & Montreal $(n=16)$ \\
\hline Areas of activity & 12 & 14 \\
$\quad$ Therapeutics & 0 & 2 \\
Diagnostics & & \\
Development stage & $0 \%$ & $6 \%$ \\
$\quad$ Research & $25 \%$ & $6 \%$ \\
$\quad$ Preclinical & $17 \%$ & $19 \%$ \\
$\quad$ Phase I & $17 \%$ & $38 \%$ \\
$\quad$ Phase II & $17 \%$ & $13 \%$ \\
$\quad$ Phase III & $25 \%$ & $19 \%$ \\
$\quad$ Marketing & 11 & 8 \\
Median age of firms & 2 & 1 \\
Median number of patents & 4 & 4 \\
Median number of products & 115 & 25 \\
Median number of employees & $92 \%$ & $69 \%$ \\
Firms with venture-capital & 59 & 20 \\
Median amount of venture-capital received (M\$) & $58 \%$ & $50 \%$ \\
Firms in the stock market & 29 & 4 \\
Median amount of IPO (M\$) & 2 & 3.5 \\
Median number of international strategic alliances & & \\
\hline
\end{tabular}

Table 2 Repartition of 430 strategic alliances according to cluster and partners localisation

\begin{tabular}{lcc}
\hline Partners localisation & Boston $(n=12)$ & Montreal $(n=16)$ \\
\hline Local strategic alliances & 93 & 87 \\
International strategic alliances & 71 & 179 \\
Total strategic alliances & 164 & 266 \\
\hline
\end{tabular}

Table 3 Characteristics of 430 total strategic alliances in human health biotechnology firms

\begin{tabular}{lcc}
\hline Total strategic alliances & Boston $(n=12)$ & Montreal $(n=16)$ \\
\hline Goals & 75 & 135 \\
R\&D & 1 & 8 \\
Production & 7 & 48 \\
Marketing & 81 & 75 \\
Several functions or undetermined & & \\
R\&D partners & 19 & 78 \\
Universities & 54 & 34 \\
Firms & 2 & 23 \\
Other organisations &
\end{tabular}


Table 3 Characteristics of 430 total strategic alliances in human health biotechnology firms (continued)

\begin{tabular}{lcc}
\hline Total strategic alliances & Boston $(n=12)$ & Montreal $(n=16)$ \\
\hline Governance structure & 20 & 62 \\
$\quad$ In-licensing & 75 & 135 \\
Cooperation in R\&D & 30 & 4 \\
Out-licensing & 3 & 2 \\
Joint ventures & 18 & 0 \\
Mergers and acquisitions & 18 & 63 \\
Others & & \\
Corporate partner size & 61 & 72 \\
$\quad$ Small and medium size enterprises & 59 & 30 \\
Large enterprises & 25 & 122 \\
Undetermined & 164 & 266 \\
Total strategic alliances &
\end{tabular}

Table 4 Characteristics of 180 local strategic alliances in human health biotechnology firms

\begin{tabular}{|c|c|c|}
\hline Local strategic alliances & Boston $(n=12)$ & Montreal $(n=16)$ \\
\hline \multicolumn{3}{|l|}{ Goals } \\
\hline $\mathrm{R} \& \mathrm{D}$ & 42 & 50 \\
\hline Production & 1 & 3 \\
\hline Marketing & 3 & 10 \\
\hline Several functions or undetermined & 47 & 24 \\
\hline \multicolumn{3}{|l|}{ R\&D partners } \\
\hline Universities & 6 & 36 \\
\hline Firms & 35 & 6 \\
\hline Other organisations & 1 & 8 \\
\hline \multicolumn{3}{|l|}{ Governance structure } \\
\hline In-licensing & 14 & 22 \\
\hline Cooperation in $\mathrm{R} \& \mathrm{D}$ & 42 & 50 \\
\hline Out-licensing & 12 & 2 \\
\hline Joint ventures & 2 & 1 \\
\hline Mergers and acquisitions & 13 & 0 \\
\hline Others & 10 & 12 \\
\hline \multicolumn{3}{|l|}{ Corporate partner size } \\
\hline Small and medium size enterprises & 40 & 15 \\
\hline Large enterprises & 29 & 8 \\
\hline Undetermined & 18 & 64 \\
\hline Total local strategic alliances & 93 & 87 \\
\hline
\end{tabular}


Table 5 Characteristics of 250 international strategic alliances in human health biotechnology firms

\begin{tabular}{lcc}
\hline International strategic alliances & Boston $(n=12)$ & Montreal $(n=16)$ \\
\hline Goals & 33 & 85 \\
R\&D & 0 & 5 \\
Production & 4 & 38 \\
Marketing & 34 & 51 \\
Several functions or undetermined & & \\
R\&D partners & 13 & 42 \\
Universities & 19 & 28 \\
Firms & 1 & 15 \\
Other organisations & & \\
Governance structure & 6 & 40 \\
In-licensing & 33 & 85 \\
Cooperation in R\&D & 18 & 2 \\
Out-licensing & 1 & 1 \\
Joint ventures & 5 & 0 \\
Mergers and acquisitions & 8 & 51 \\
Others & & \\
Corporate partner size & 21 & 57 \\
Small and medium size enterprises & 30 & 22 \\
Large enterprises & 7 & 58 \\
Undetermined & 71 & 179 \\
Total international strategic alliances & & \\
\hline
\end{tabular}

Yet, contrary to intuitive expectations and literature prognostics, and in spite of their younger age, Montreal's firms are overall conducting more strategic alliances than Boston's firms: 16.6 strategic alliances for Montreal's DBFs versus 13.7 for Boston's firms. This is also true for international strategic alliances. Data suggest that in terms of goals and governance structure, the comparison pattern of Boston and Montreal firms stands at both the national and international level. Exceptions are observed for R\&D partners with firms where Boston companies outnumber Montreal firms at the national level. In fact, corporate partnerships in the home market, regardless of the size, are more frequent in Boston. However, Montreal outperforms again in its international strategic alliances with SMEs.

As for the comparison between national and international strategic alliances in each cluster, Montreal firms register more international strategic alliances, regardless of the characteristics. As for Boston's firms, most of the agreements are more common in the home market, except for marketing strategic alliances, R\&D partnerships with universities, and agreements with large firms.

While looking at the age of the firm at which the first international alliance occurred, overall, Montreal firms are active earlier in foreign markets. However, depending on the measure used (mean or median), this precocity is obvious in North America, probable in Europe, but uncertain in Asia. 
Table 6 Internationalisation speed and scope of human health biotechnology firms

\begin{tabular}{lcccccc}
\hline \multirow{2}{*}{ Age at first international strategic alliances (years) } & \multicolumn{2}{c}{ Boston $(n=12)$} & & \multicolumn{2}{c}{ Montreal $(n=16)$} \\
& & Mean & Median & & Mean & Median \\
\hline Overall first international strategic alliance & 5.7 & 2 & & 2.8 & 1.5 \\
In North America & 6.8 & 3 & & 3 & 1.5 \\
In Europe & 7.6 & 5 & & 5.6 & 5 \\
In Asia & 11.8 & 6 & & 8 & 8 \\
\hline
\end{tabular}

\section{Discussion}

This study extended knowledge about the impact of the country of origin on firms' cooperation behaviour (Lemarié et al., 2001; Fontes, 2005). Proposition 1 posits that DBFs evolving in a scarce venture-capital home environment conduct more international strategic alliances, which is consistent with our findings. DBFs in Boston and Montreal clusters have distinct profiles. There is a substantial difference between Boston and Montreal firms in terms of age, number of employees, percentages of firms that obtained venture capital and the amount raised, both from venture capital and IPOs. Thus, experience, financial and available human resources being very different for firms from these two regions, we could expect an impact on their business models and therefore, on their international strategic alliances' strategy.

Existing literature takes for granted that the more venture-capital a firm receives, the higher the number of international strategic alliances it will conclude, because the invested-in DBF has obtained the endorsement of the selective risk capital (Baum and Silverman, 2004). In our study, the opposite seems true. Boston DBFs in our sample prefer to remain at a distance from partners as long as possible, in order to increase the value of the incipient technology and avoid a sell-off situation. An explanation might be that strategic alliances can reduce revenues through profit sharing and expose themselves to possible opportunistic exploitation by their partners. On the other hand, in order to grow, in a context of scarce venture-capital, biotechnology firms use strategic alliances as an alternative source of seed capital.

Received knowledge (Hsu, 2006) also states that biotechnology start-ups with abundant venture-capital will be faster in concluding technology strategic alliances with large corporate partners, compared with small firms with scarce venture-capital support. It is consistent with our findings, but it might also be examined from a previous corporate experience point of view. While Boston firms develop more strategic alliances with SMEs at the local level, this experience might be transposed at the international level because more strategic alliances with large firms have been signed. However, this does not apply to Montreal firms that are still registering more strategic alliances with SMEs at the international level. Once again, their organisational and financial profile might not give them sufficient credibility for large firms; previous experience with corporate partners would then not be enough. Therefore, our results are consistent with venture-capital as a key condition for growth.

Ozmel et al. (2012) also found that strategic alliances and venture-capital can substitute for each other. While venture-capital favours other venture-capital investments and strategic alliances activities, partnerships reduce future investments because of 
potential conflict of interest between organisations. Indeed, Boston firms have fewer overall international strategic alliances, but being more advanced in product development, they have more technology to out-license and are more attractive for joint ventures, mergers and acquisitions. Differences in governance structures, both at the local and international levels, reflect Montreal firms' younger age and lower stage of development. They are still more involved in research and upstream activities, as indicated by their extensive use of in-licensing and R\&D collaborations.

According to the outstanding total number of strategic alliances of Montreal firms, they seem indeed to compensate with strategic alliances. While looking at the localisation of their partners, since their environment contains fewer potential firms to collaborate with (van Beuzekom and Arundel, 2009), it makes sense that they are outnumbered by Boston companies. Because of the strength of US biotechnology industry, R\&D partners with the required complementary knowledge are more often found on the national scale for Boston firms. Montreal companies, however, are more active in R\&D partnerships with universities. The alternatives chosen by Montreal firms to overcome their financial issues are more striking at the international scale. They register an impressive number of strategic alliances for R\&D, regardless of the type of partners, production, and marketing. Firms with little venture-capital are not the ones with a higher number of overall corporate partners, neither at the local level nor with large foreign firms. In fact, they only outperform with partnerships with international SMEs. Being younger with products at a lower development stage, with fewer patents and venture-capital endorsements, they might not have the necessary credibility to attract large partners. Results indicate that strategic alliances are indeed not the most important factor for DBFs' growth (Niosi, 2003). Proposition 1 is therefore confirmed.

Proposition 2 states that the timing of the first international strategic alliance is related to the availability of venture-capital in the home market: the lower the amount of venture-capital, the faster the entry into international strategic alliances. Montreal's firms, evolving in a scarce capital venture environment, have been concluding international strategic alliances earlier than their Boston counterparts. This confirms Proposition 2. However, when looking closely at the age at which they penetrate each continent, this international implication has its limitations. This might be explained by the required resources to meet and maintain relationships with partners that are in distant markets. The implication of this finding is that biotechnology firms do not necessarily need to conduct corporate strategic alliances early on, if they are able to find adequate support from angel and venture-capital or from capital markets during and after IPO (Ozmel et al., 2012).

They may prefer to 'go it alone' before they request large corporate partners' financial and knowledge support.

\section{Conclusions}

This exploratory study was hoping to shed light on the impact of international strategic alliances in DBFs' growth, specifically in the human health sector, in an environment characterised by scant venture-capital. By examining two different clusters, namely Boston and Montreal, it described how different DBFs' organisational characteristics and strategic alliances portfolio could be. It highlights the range of difference in the financing of Boston and Montreal firms and its impact on strategic alliance characteristics. Still being in the start-up stage, Montreal firms are multiplying R\&D strategic alliances with 
universities and SMEs, while Boston firms with products at a later development stage can out-license their technologies and work with large firms. The age at which Montreal firms must internationalise and the extent to which they manage foreign partnerships are outstanding. International strategic alliances seem therefore to be a second-best option for firms evolving in an environment with scarce resources. Our exploratory study shows that international comparisons, especially between large and small size market countries, may uncover substantial differences in company strategy. On the northern side of the border, Montreal companies start their corporate partnering early, but do not grow faster or bigger under this type of environment. Boston biotechnology firms, on the contrary, seem more able to experience rapid grow in a setting of more abundant and more experienced venture-capital. Although these are preliminary results, international strategic alliances seem more critical for Montreal than for Boston firms.

Further research should verify these preliminary findings with larger samples in all main Canadian and US human health biotechnology clusters allowing statistical analysis. Distinctive statistically valid samples of therapeutics and diagnostics firms could provide insights on different international alliance strategies and portfolios. Comparison of other human health biotechnology clusters from both large and small home venture-capital markets would provide more in-depth information on the potential of generalisation of these results.

\section{Acknowledgements}

The author would like to thank Prof. Jorge Niosi, Dr. Andrée G. Roberge, Prof. Johanne Queenton, and three anonymous reviewers for their valuable comments. This research was funded by the Social Sciences and Humanities Research Council of Canada, and the Canada Research Chair on the Management of Technology.

\section{References}

Baum, J.A.C. and Silverman, B.S. (2004) 'Picking winners or building them? Alliance, intellectual and human capital as selection criteria in venture financing and performance of biotechnology start-ups', Journal of Business Venturing, Vol. 19, No. 3, pp.411-436.

Baum, J.A.C., Calabrese, T. and Silverman, B.S. (2000) 'Don't go it alone: alliance network composition and start-ups' performance in Canadian biotechnology', Strategic Management Journal, Vol. 21, No. 3, pp.267-294.

Coombs, J.E. and Deeds, D.L. (2000) 'International alliances as sources of capital: evidence from the biotechnology industry', Journal of High Technology Management Research, Vol. 11, No. 2, pp.235-253.

Das, T.K. and Teng, B.S. (2000) 'A resource-based theory of strategic alliances', Journal of Management, Vol. 26, No. 1, pp.31-61.

Deeds, D.L. and Hill, C.W. (1996) 'Strategic alliances and the rate of new product development: an empirical study of entrepreneurial biotechnology firms', Journal of Business Venturing, Vol. 11, No. 1, pp.41-55.

Ernst \& Young (2009) Beyond Borders: Global Biotechnology Report 2009, Ernst \& Young, New York.

Fontes, M. (2005) 'Distant networking: the out cluster biotechnology strategies of new biotechnology firms', in Green, K., Miozzo, M. and Dewick, P. (Eds.): Technology, Knowledge and the Firm, pp.152-178, Elgar, Cheltenham. 
Gilding, M. (2008) 'The tyranny of distance: biotechnology networks and clusters in the antipodes', Research Policy, Vol. 37, Nos. 6-7, pp.1132-1144.

Gomes-Casseres, B., Hagedoorn, J. and Jaffe, A.B. (2006) 'Do strategic alliances promote knowledge flows?', Journal of Financial Economics, Vol. 80, No. 1, pp.5-33.

Gulati, R. (1995) 'Does familiarity breed trust? The implications for repeated ties for contractual choices in strategic alliances', Academic Management Journal, Vol. 38, No. 1, pp.85-112.

Gulati, R. (1998) 'Strategic alliances and networks', Strategic Management Journal, Vol. 19, No. 4, pp.293-317.

Hsu, D.H. (2006) 'Venture capitalists and cooperative start-up commercialization strategy', Management Science, Vol. 52, No. 2, pp.204-219.

Kogut, B. (1989) 'The stability of joint ventures: reciprocity and competitive rivalry', Journal of Industrial Economics, Vol. 38, No. 2, pp.183-198.

Lemarié, S., Mangematin, V. and Torre, A. (2001) 'Is the creation and development of biotech SMEs localised? Conclusions drawn from the French case', Small Business Economics, Vol. 17, Nos. 1-2, pp.61-76.

Lerner, J. and Merges, R.P. (2000) 'The control of technology strategic alliances: an empirical analysis of the biotechnology industry', The Journal of Industrial Economics, Vol. 46, No. 2, pp.125-156.

Li, N., Boulding, W. and Staelin, R. (2010) 'General alliance experience, uncertainty, and marketing alliance governance mode choice', Journal of the Academy of Marketing Science, Vol. 38, No. 2, pp.141-158.

Madhok, A. and Osegowitsch, T. (2000) 'The international biotechnology industry: a dynamic capabilities perspective', Journal of International Business Studies, Vol. 31, No. 2, pp.325-335.

McKelvey, M., Alm, H. and Riccaboni, M. (2003) 'Does co-location matter for formal knowledge collaboration in the Swedish biotechnology pharmaceutical sector?', Research Policy, Vol. 32, No. 3, pp.483-501.

Niosi, J. (2003) 'Strategic alliances are not enough explaining rapid growth in biotechnology firms', Research Policy, Vol. 32, No. 5, pp.737-750.

Niosi, J. (2005) Canada's Regional Innovation System, The Science-based Industries, McGill-Queen's University Press, Montreal.

Niosi, J. and Banik, M. (2005) 'The evolution and performance of biotechnology regional systems of innovation', Cambridge Journal of Economics, Vol. 29, No. 3, pp.343-357.

Niosi, J. and Bas, T.G. (2001) 'The competencies of regions: Canada's clusters in biotechnology', Small Business Economics, Vol. 17, Nos. 1/2, pp.31-42.

Organisation for Economic Co-operation and Development (OECD) (2006) OECD Biotechnology Statistics, Paris.

Ozmel, U., Robinson, D.T. and Stuart, T.E. (2012) 'Strategic alliances, venture capital, and exit decisions in early stage high-tech firms', Journal of Financial Economics, Vol. 107, No. 3, pp.655-670, http://dx.doi.org/10.1016/j.jfineci.2012.09.009.

Powell, W.W., Koput, K., Bowie, J.I. and Smith-Doerr, L. (2002) 'The spatial clustering of science and capital: accounting for biotech-venture capital relationships', Regional Studies, Vol. 36, No. 3, pp.291-395.

Rothaermel, F.T. and Deeds, D.L. (2006) 'Alliance type, alliance experience and alliance management capability in high-technology ventures', Journal of Business Venturing, Vol. 21, No. 4, pp.429-460.

Thomson Reuters (2009) Private Equity Canada 2008. The Industry at an Inflexion Point, Thomson, Toronto.

Tyebjee, T. and Hardin, J. (2004) 'Biotech-pharma strategic alliances: strategies, structures and financing', Journal of Commercial Biotechnology, Vol. 10, No. 4, pp.329-339. 
van Beuzekom, B. and Arundel, A. (2009) OECD Biotechnology Statistics 2009, OECD editions, Paris.

Veilleux, S., Haskell, N. and Pons, F. (2011) 'Influence of entry modes on communication strategies of international new ventures in foreign markets: a preliminary study', International Journal of Business and Globalisation, Vol. 6, No. 2, pp.117-135.

Veilleux, S., Haskell, N. and Pons, F. (2012) 'Going global: how smaller enterprises benefit from strategic alliances', Journal of Business Strategy, Vol. 33, No. 5, pp.22-31.

Zollo, M., Reuer, J.J. and Singh, H. (2002) 'Interorganizational routines and performance in strategic alliances', Organization Science, Vol. 13, No. 6, pp.701-713.

\section{Notes}

1 In its latest report, the OECD defined DBFs "as a biotechnology firm whose predominant activity involves the application of biotechnology techniques to produce goods or services and/or to perform biotechnology R\&D" [van Beuzekom and Arundel, (2009), p.10]. However, some disparities exist depending on the application fields of these technologies: health (human and animal), agro-food, natural resources, environment, industrial processing, and bioinformatics. Because of these different realities, the present study focus on human health biotechnology firms specialised "in the development, production, prescribing of therapeutics, in vivo diagnostics, and vaccines" [van Beuzekom and Arundel, (2009), p.84]. 